\title{
四国中央部中央構造線付近に発生する 微小地震の震源分布
}

\author{
地質調查所* 佐藤 隆司 - 当舎利行 - 長 秋 雄 - 増田幸治
}

\section{Hypocenter Distribution of Microearthquakes around a Central Portion of the Median Tectonic Line in Shikoku, Southwest Japan}

\author{
Takashi Satoh, Toshiyuki Tosha, Akio Cho and Koji Masuda \\ Geological Survey of Japan, 1-1-3, Higashi, Tsukuba, Ibaraki 305, Japan \\ (Received July 26, 1993; Accepted November 17, 1993)
}

\begin{abstract}
Although the Median Tectonic Line (MTL) fault system in Shikoku, southwest Japan, is one of the most active faults during the late Quaternary in Japan, the present-day seismicity along the MTL is not so remarkable. However microseismic activities have recently been reported in some regions along the MTL in Shikoku. It has been pointed out that these activities are those at segment boundaries of the MTL fault system. We carried out a temporal microseismic observation in one of these regions, the region around borders between Ehime, Kagawa and Tokushima prefectures, in order to determine the earthquake hypocenters precisely so that we can discuss the hypocenter distribution in context of the tectonics of the MTL. The seismometer network consisted of six observation points and had its areal extent of about $10 \mathrm{~km}$ by $10 \mathrm{~km}$. Surface trace of the Ikeda fault goes through the network with its strike of $N 75^{\circ} \mathrm{E}$. About $10 \mathrm{~km}$ to the west of the network, there is a segment boundary of the MTL fault system which divides the Ikeda fault and the Ishiduchi fault. Hy pocenters of 82 earthquakes are located during November 1990-August 1991. The seismic activity is high beneath the network, and no hypocenter is located near the segment boundary of the Ikeda and Ishiduchi faults. Most events located in the southern side of the MTL are in a depth range of $5-8 \mathrm{~km}$, and the distribution is almost flat or slightly inclines toward south from the MTL. The distribution pattern of the hypocenters in the northern side of the MTL is widely different from that in the southern side. The hypocenter depth increases with being away northward from the surface trace of the MTL. Although the number of events located is too few to conclude that the distribution is planar, the dip angle of about $50^{\circ}$ is measured from a cross-sectional view on a vertical plane perpendicular to the strike of the MTL. The gap in the hypocenter distribution just beneath the MTL dipping almost vertically to the north, which has been reported by KimURA and ОкаNо (1992) as an evidence that the MTL is near vertical, is not found in the present study.
\end{abstract}

Key words: Median Tectonic Line (MTL), Shikoku, Microeathquakes, Fault Segmentation.

\section{§1.はじめに}

中央構造線（Median Tectonic Line，以下 MTL と略 す）活断層系は，日本の内陸地域における第一級の活断 首であり，四国地域においてはその大部分が活動度 $\mathrm{A}$ またはBに分類される [活断層研究会 (1980)]. MATsuDA (1980) は, 平均相対変位速度が大きいこと, および,

* 于305 茨城県つくば市東 1-1-3
歷史に残る被害地震の記録がないことから，MTL を近 い将来大地震の発生する可能性の高い要注意断層のひと つとした.

近年, トレンチや物理探査の手法を用いて活断層の第 四紀後期の活動を解読する試みが数多くなされており， 四国およびその周辺の MTL 活断層系においてもいくつ かの報告例がある. 小川・他 (1992) は, 伊予灌北東部の 海底活断層の音波探查記録やコアサンプルを用いた堆積 


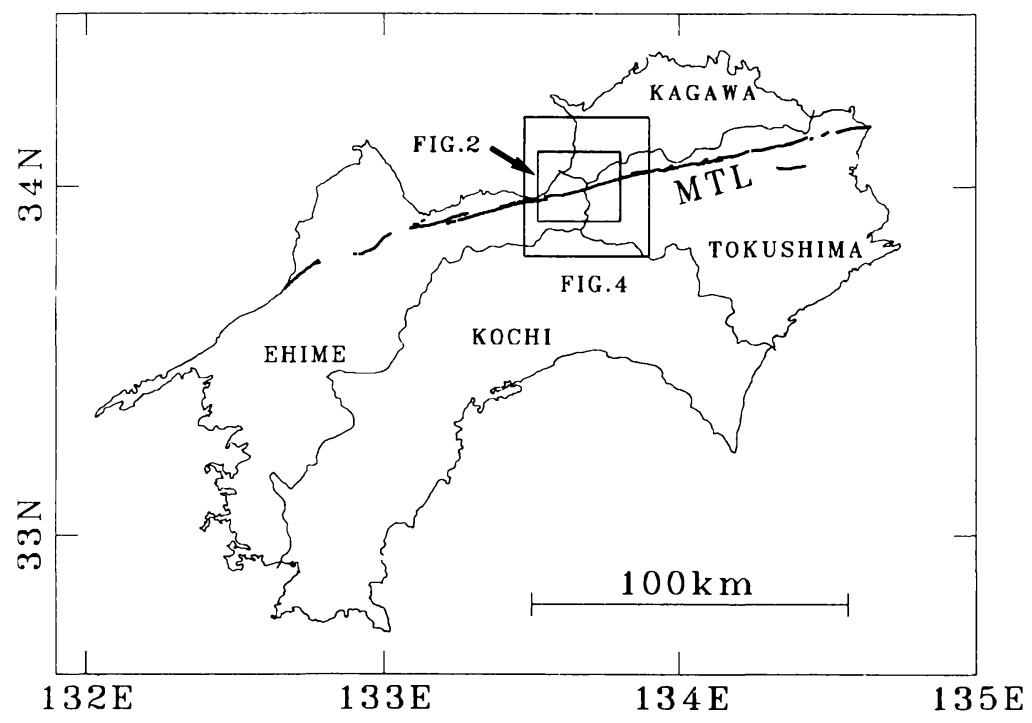

Fig. 1. Map of Shikoku showing location of the study area. Areas enclosed by the smaller and bigger squares correspond to those covered by Fig. 2 and Fig. 4, respectively. Surface trace of the MTL is drawn by thick lines.

層の対比から，同断層の最新の活動が約 2000 年前, 活 動の周期が約 2000 年と推定した。愛媛県岡村断層にお ける Tsutsumi et a!. (1991), 堤・他 (1992), 山崎・他 (1992)によるトレンチ調查の結果から, 同断層の最新活 動時期, 活動周期は, それぞれ，4～7 世紀，1300〜 2000 年程度と推定されている. 岡田・他 (1991) は徳島 県父尾断層におけるトレンチ調査から同断層が 1596 年 の慶長地震 $(M 7.5)$ の震源である可能性が高いことを指 摘し，MTL 活断層系を震源とする歴史地震はないとい うこれまでの常識が必ずしも正しくないことを示した。

これらの研究から明らかになってきた最も重要なこと のひとつは, MTL 活断層系が, 全体が同一時期に活動 する一括放出型の活断層ではなく，活動時期の異なるい くつかの区間（セグメント）によって構成されているこ とである. 実際, 最近では, MTL 活断層系をセグメント に分割する試みが佃 (1990)，岡田 (1992) によりなされ ている.このようにひとつの活断層系がいくつかのセグ メントに分かれている場合, セグメント境界は大地震の 破壊開始点になる可能性が高い. 従って, そのような場 所で種々の観測を継続して行い地款活動の変化をとらえ ることは大地震の前兆現象をとらえるうえで非常に重要 になる。

四国内ではMTL に直接関連すると考えられる現在の 地震活動はあまり活発ではない，しかし，近年の国立大 学の微小地震観測網の拡充にともない, 徳島県徳島市北 西方, 徳島・香川・愛媛県境付近, 愛媛県西条市付近, 松山市東方および西方などの地域の MTL 近傍に浅発微
小地震活動の集中域が存在することが明らかになった [三浦・他 (1990), 岡野・木村 (1988)]. 佃 $(1989,1990)$ はこれらの地震活動域がいずれす MTL のセグメント境 界付近に位置することを示すととあに，MTL の将来の 活動を予測するうえでこれらの地震活動に注目すること の重要性を指摘した。しかし, 四国内の国立大学の微小 地震観測網の観測点の密度が不十分なため, 浅い地震の 深さの決定精度が MTL との関連を議論するには必ずし あ十分でない可能性がある [岡野・木村 (1988)].

そこで我々は, 上記地震活動域のうち, 徳島・香川・ 愛质県境付近の活動について，その震源分布を精度良く 決定し，MTL との関連を明らかにする目的で， Fig. 1 に示される地域で 6 観測点からなる小スパンの微小地 震観測を行った。ここでは得られた震源分布の特徴につ いて報告する.

\section{§ 2. 観測}

観測は 1990 年 11 月から 1991 年 8 月までの約 9 か 月間行われた. Fig. 2 に観測点の配置を, Table 1 に観 測点の座標を示す. 観測網は, 岡野・木村 (1988)による 震源分布を参考に, 深さ $5 \mathrm{~km}$ 以浅の地震の震央を取り 囲むように設定した。観測網は東西・南北の広がり約 $10 \mathrm{~km}$, 観測点の間隔約 $5 \mathrm{~km}$ で, そのほぼ中央を MTL 活断層系のひとつ, 池田断層, が $\mathrm{N} 75^{\circ} \mathrm{E}$ の走向に発達 している. 観測点は池田断層の北側に 2 点, 南側に 4 点 の合計 6 点を設置した. ちなみに，この付近における国 立大学の微小地震観測網の観測点の間隔は約 $30 \mathrm{~km}$ 以 


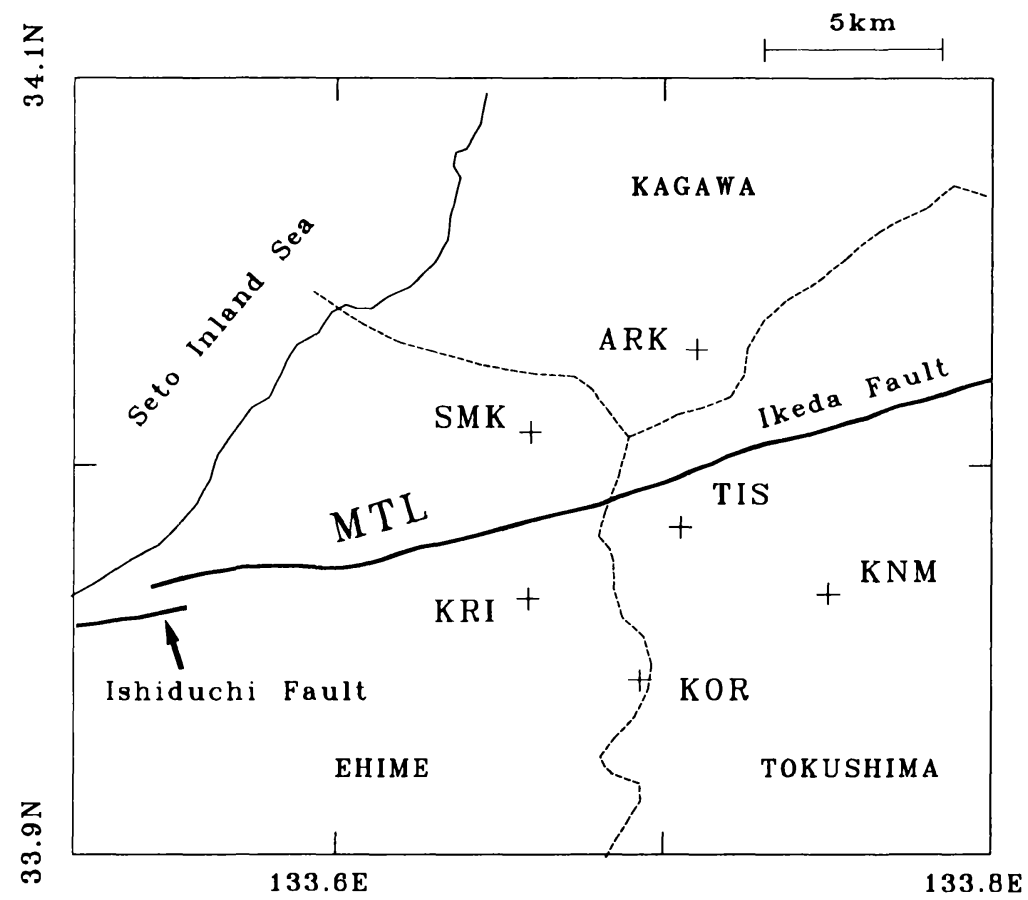

Fig. 2. Distribution of the seismograph stations (Crosses). Thick solid lines indicate surface trace of the MTL. Thin solid and dashed lines denote the coast line and the prefectural borders, respectively.

上である．観測網の西約 $10 \mathrm{~km}$ の愛媛県伊予三島市内 には MTL の地表トレースのギャップが存在し, 池田断 首とその西の石槌断層を画するセグメント境界とされて いる [岡田 (1992), 佃 (1990)].

観測システムは，地質調査所において地熱地域の微小 地震探查のために開発されたもの [当舎・他 (1989)] で あり, 岩手県滝/上地域における微小地震観測などで実 績をあげている [当舎・他 (1990)]．各観測点には固有 周波数 $2 \mathrm{~Hz}$ の 3 成分速度型地震計（マークプロダクト L22-D）が設置された。地震計によって検出された地動 信号は, プリアンプで $40 \mathrm{~dB}$ 增幅された後, ディジ夕 ル・イベント・レコーダ（コロンビア貿易 DTC-7000） に入力された。 入力された信号は，レコーダ内蔵のメイ ンアンプでさらに $20 \mathrm{~dB}$ 增幅された後 $200 \mathrm{~Hz}$ サンプリ ング, 16 ビット分解能で $\mathrm{A} / \mathrm{D}$ 変換され，トリガ方式で カートリッジテープに記録された．本観測システムはテ レメータ方式によるものではないが, 各レコーダには精 度 $10^{-10}$ の水晶時計が内蔵されており, 同精度の可搬型 のマスター時計（コロンビア貿易 TMC-6010）を用いて 2 週間に 1 度程度の頻度で校正を行うことにより, 観測 点間の時刻同期を $1 \mathrm{~ms}$ 程度の精度に保つことができ る.また，マスター時計をJJY 自動校正機能付きの時計

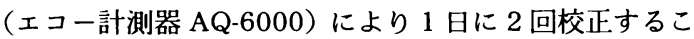

Table 1. List of Seismograph Stations.

\begin{tabular}{llccc}
\hline \hline $\begin{array}{c}\text { Station } \\
\text { name }\end{array}$ & Code & $\begin{array}{c}\text { Latitude } \\
\left({ }^{\circ} \mathrm{N}\right)\end{array}$ & $\begin{array}{c}\text { Longitude } \\
\left({ }^{\circ} \mathrm{E}\right)\end{array}$ & $\begin{array}{c}\text { Elevation } \\
(\mathrm{m})\end{array}$ \\
\hline Ariki & ARK & 34.0298 & 133.7100 & 430 \\
Daiso & TIS & 33.9839 & 133.7052 & 605 \\
Kioroshi & KOR & 33.9448 & 133.6929 & 500 \\
Kureishi & KRI & 33.9656 & 133.6586 & 580 \\
Shimokawa & SMK & 34.0085 & 133.6592 & 295 \\
Terano & KNM & 33.9669 & 133.7503 & 365 \\
\hline
\end{tabular}

とにより $5 \mathrm{~ms}$ 程度の精度で日本標準時刻との比較を可 能とした.

\section{§3. 震源決定}

震源計算には，P波および $\mathrm{S}$ 波の初動到達時刻を用 い，MATSU'URA (1984) の提案した方法にもとづいて HiRATA and Matsu'URA (1987) が開発したプログラム が用いられた. MATSU'URA (1984)の方法では, 事前の 情報に基づいて与えられた震源パラメ夕に関する先験的 確率密度分布と観測データから計算される尤度の積, す なわち事後確率密度分布，を最大にする震源パラメ夕が

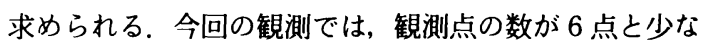
いことや，観測網の広がりが $10 \mathrm{~km} \times 10 \mathrm{~km}$ 程度とあ まり広くなく観測網の外に発生する地震 震源決定の対 


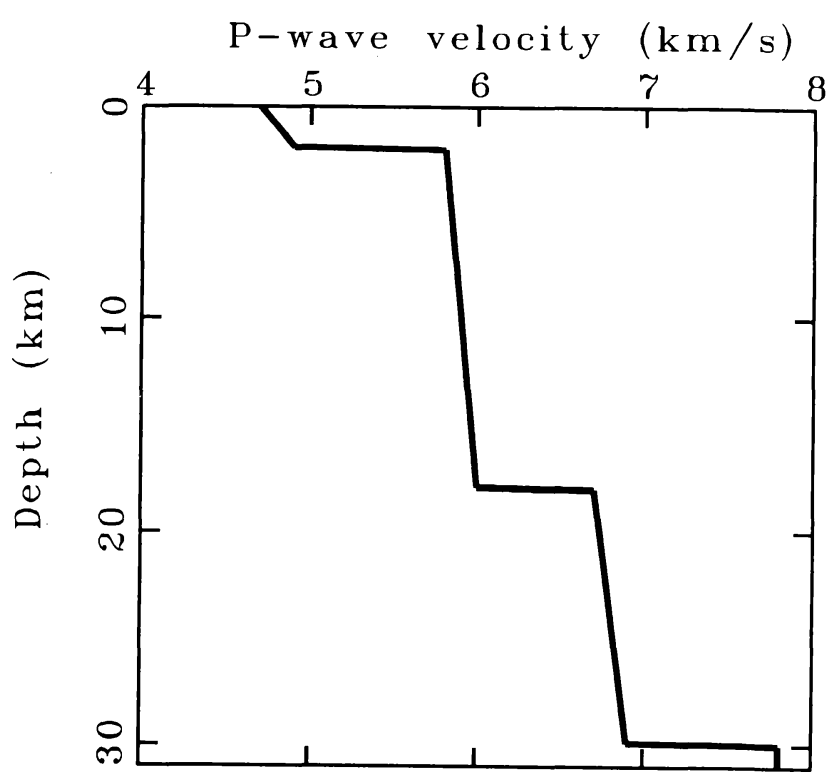

Fig. 3. P-wave velocity structure model used for locating the earthquake hypocenters. $V_{\mathrm{p}} / V_{\mathrm{s}}$ is assumed to be 1.73 .

象にしなければならないことから，安定に解が得られる 震源決定法のひとつである MATSU'URA (1984) の方法を 採用した。

速度構造モデルは, 付近で害施された屈折法地震探查 [井上・他 (1984), 伊藤・他 (1982)］の結果を参考にし て, Fig. 3 に示されるあのが用いられた. $V_{\mathrm{p}} / V_{\mathrm{s}}$ は 1.73 と仮定した，上記の地震探査の結果から, MTL 直下に おいて, P 波速度 $4.8 \mathrm{~km} / \mathrm{s}$ の第 1 層と約 $6 \mathrm{~km} / \mathrm{s}$ の第 2 層の境界の深さに $2 \mathrm{~km}$ 程度の北落ちの段差か認めら れるが, 震源決定ではこのことは考虑されていない，震 源決定に用いた Fig. 3 に示される速度構造は, MTLの 南側のそれに近い構造である.

3 点以上の観測点で初動の検測がなされ S-P が 2.5 秒 以下の地震を対象に震源決定を行った. 観測網は岡野・ 木村 (1988) を参考にして付近で発生する深さ $5 \mathrm{~km}$ 以 下の地震の震央を取り囲むように設定した。従って, 震 源位置の先験的確率密度分布は観測網のほぼ中央 $\left(34^{\circ} \mathrm{N}, 133.7^{\circ} \mathrm{E}\right)$, 深さ $10 \mathrm{~km}$ に中心を持ち, 水平方向 の分散 $(100 \mathrm{~km})^{2}$, 鉛直方向の分散 $(20 \mathrm{~km})^{2}$ の正規分布 とした. 空中に震源が決定されるのを防ぐために鉛直方 向の拘束を比較的強く設定した。

震源決定の精度について以下のふたつの影響について 調べた.ひとつはランダムな読み取り誤差の影響であ り,もうひとつは屈折法地震探査の結果明らかになった 地殼浅部における MTL の南と北の構造の違い [井上・ 他 (1984)，伊藤・他 (1982)] を考虑に入れなかったこと の影響である.
震源決定は非線形最小二乗法の問題なので, ランダム な読み取り誤差が震源決定精度におよぼす影響は共分散 行列から正しく評価できるとは限らない。ここでは, 観 測デー夕に正規乱数を加えたものをデー夕として震源決 定を行い，そのばらつきからランダムな読み取り誤差の 影響を調べた. SA To et al. (1967) は理論走時に正規乱数 を加えたデー夕を使って同様のシミュレーションを行う ことにより気象庁の地震観測網の震源決定精度を評価し ている. 正規乱数の標準偏差は観測波形を参考にして $\mathrm{P}$ 波 0.02 秒, $\mathrm{S}$ 波 0.1 秒とし, シミュレーションは各地震 について 200 回行った. シミュレーションの結果は共分 散行列から推定される震源決定の精度とともに震源決定 結果の取捨選択の基準として用いた。

次に, 地殻浅部における MTL の南と北の速度構造の 違いを考慮にいれていないことの影響について調べるた め, MTL の北側の観測点 (ARK, SMK) の観測値に $\mathrm{P}$ 波 で -0.08 秒, $\mathrm{S}$ 波で-0.14 秒の観測点補正を加えて震 源決定を行った。この観測点補正檤は地震波が真下から 入射した場合の, 震源決定に用いた水平成層構造モデル と伊藤・他 (1982) や井上・他 (1984) によって見いださ れた段差のある構造との走時差に相当する. 段差の影響 を正しく評価するためには 3 次元速度構造を用いた震 源決定をする必要があるが, 地震波の入射方向が真下に 近い観測網直下の地震や観測網の周辺の地震でも比较的 深いものに対しては観測点補正を与える方法で十分に評 価が可能であろう。観測点補正を加えて震源決定を行っ た結果と加えないで震源決定を行った結果を比較する 


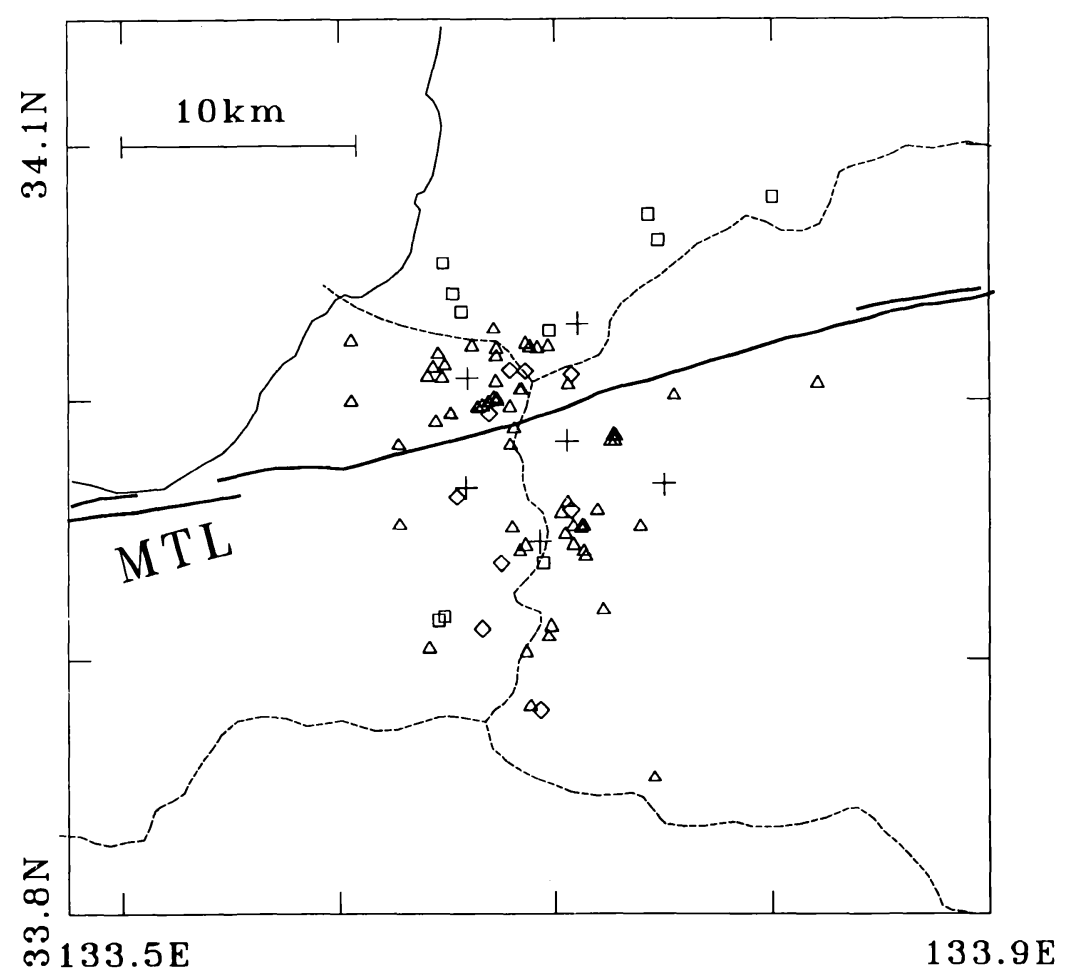

Fig. 4. Epicenter distribution. Diamonds, triangles and squares indicate the focal depth $(H): \diamond ; H \leq 5$ $\mathrm{km}, \triangle ; 5<H \leq 8 \mathrm{~km}, \square ; H>8 \mathrm{~km}$. Crosses indicate the observation points. Thick solid lines indicate surface trace of the MTL.

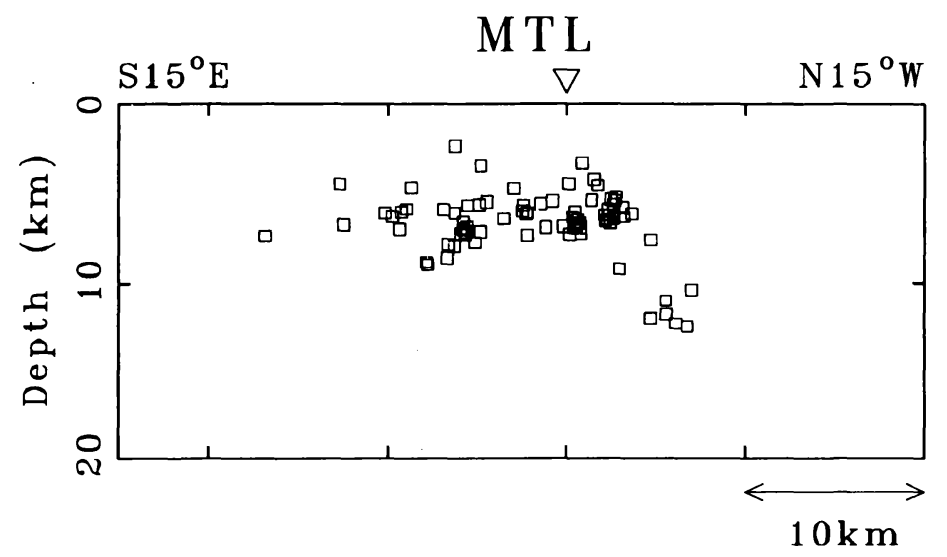

Fig. 5. Cross-sectional view of the earthquake hypocenters projected on a vertical plane striking $N 15^{\circ}$ $\mathrm{W}$, which is perpendicular to strike of the MTL. $\nabla$ indicates approximate location of surface trace of the MTL.

と, 得られた震源位置のずれは最大 $2.3 \mathrm{~km}$, 平均 0.8 $\mathrm{km}$ であり, 次節で述べる震源分布の特徴もほとんど変 わらなかった。

\section{§ 4. 辰源分布の特徽}

Fig. 4 に震央分布を示す．岡野・木村 (1988)，木村・
岡野 (1992) に従って, シンボルにより震源の深さ $(H)$ の範囲を, $\diamond: H \leq 5 \mathrm{~km}, \triangle: 5 \mathrm{~km}<H \leq 8 \mathrm{~km}, \square: H>8$ km，の 3 つに区分した. Fig. 5 は Fig. 4 にプロットさ れた地震を MTL と直交する走向 $\mathrm{N} 15^{\circ} \mathrm{W}$ の鈴直な面に 投影したものである. 共分散行列の最大固有値の方向に おける震源位置の推定值の標準偏差, および, シミュ 
レーションで求められた震源位置のばらつきが最も大き い方向におけるばらつきの標準偏差がともに $2 \mathrm{~km}$ 以下 に決定された 82 個の地震がプロットされている，上下 動成分の最大振幅から渡辺 (1971) の式を用いて決定さ れた最小の地震のマグニチュードは -0.4 である.

震源決定された地震の大部分は深さ $5 \mathrm{~km}$ から $8 \mathrm{~km}$ の範囲にあり，それらは観測網の直下の愛媛・香川・徳 島県境付近を中心に東西約 $10 \mathrm{~km}$ の範囲に分布してい る. 南北方向の広がりは, 北側が MTL の北約 $4 \mathrm{~km}$ ま での範囲に限られるのに対し, 南側は MTL から 10 数 $\mathrm{km}$ 程度南まで分布している。震央の分布は一様ではな く, MTL の北側の SMK 観測点から ARK 観測点にか けての地域, および, MTL の南約 $5 \mathrm{~km}$ の KOR 観測点 の周辺に多く決定されており, MTL のすぐ南の KRI 観 測点から TIS 観測点にかけて地震の少ない地域が帯状 に存在する．鉛直断面図 (Fig. 5) を見ると，これらの地 震はほぼ水平あるいはやや南に傾斜した分布をしてい る. 岡野・木村 (1988)などによれば, この活動はさらに 南方に続き MTL の南方約 $30 \mathrm{~km}$ を並走する御荷鉾構 造線の南にまで達している。この活動の北側に接するよ うに深さ $8 \mathrm{~km}$ よりも深い地震がいくつか分布している (Fig. 4). 鈶直断面図からはこれらの地震が MTL から遠 ざかるに従って急激にその深さを増すことが分かる (Fig. 5).これらの地震は震源決定された地震の数が少な くそれらが面状に分布しているか否かを断定することは できないが，傾斜角を測ると約 $50^{\circ}$ になる．深さ $8 \mathrm{~km}$ 以浅の地震の分布の北限むほぼ同じ角度で北に傾斜して いるように見える。観測網の西方約 $10 \mathrm{~km}$ の伊予三島 市内にある池田断層と石槌断層とのセグメント境界付近 には今回の観測では震源は決定されなかった。

この周刃で発生する地震の震源分布については, 四国 内およびその周辺の国立大学の微小地震観測網のデー夕 をまとめた岡野・木村 (1988) に最近の知見およびデー 夕を加えた，木村・岡野 (1992) に最も詳しく述べられ ている. 今回の観測で得られた結果は, MTL の南側に は南に緩く傾斜する $8 \mathrm{~km}$ より浅い地震が分布し, 北側 には北に向かって急激に深さを增す地震が分布する，上 いう全体的な特徴については木村・岡野 (1992) と一致 する.ここではさらに細かな点について彼らの結果と比 較する. 木村・岡野 (1992)によれば，この地域の $8 \mathrm{~km}$ より浅い地震の震央分布には $\mathrm{NE}-\mathrm{SW}$ 方向に走向を持 つ線状配列が認められる. またこの配列は MTL を境に して北側が西にずれており，MTL の南側の活動との間 に地震活動の陌間が認められる. 今回の観測で得られた 震央分布 (Fig. 4) でも, 前述のように, MTL の北と南に ふたつの活動域が認められる。このうち KOR 観測点付
近の地震活動についてはその周辺の地震と合わせて考え ると NE-SW に近い走向で線状配列しているようにも 見える. また，MTL の北側の地震活動の位置は南側の 分布の線状配列の延長より西側に分布しており，木村・ 岡野 (1992) の結果と調和的である. しかし, MTLの北 側の $8 \mathrm{~km}$ より浅い地震は, NE-SW 方向に配列してい るというょりむ，むしろ，MTL の走向の方向に配列し ているように見える. 木村・岡野 (1992) はさらに，深さ $8 \mathrm{~km}$ より浅い地震の震源分布の MTL 直下に鉛直に近 い北傾斜の北落ちの食い違いが存在することを指摘して いるが，今回の観測で得られた震源分布の鉛直断面図 (Fig. 5) からはそのような食い違いを認めることはでき ない.

\section{§ 5. 議論}

今回の観測では池田断層と石㮸断層のセグメント境界 付近には震源が決定されなかった. Fig. 4 は S-P 2.5 秒 以下の地震がプロットされているが, S-P 3 秒までの地 震をとってもこの付近に震源を持つ地震は見られない． このセグメント境界は観測網の西方約 $10 \mathrm{~km}$ の所にあ り，震源決定能力があまり高くない地域にある，また観 測期間があまり長くないので, この付近に地震が発生し ていないと断定することはできない，しかし，観測網の 南方ではこのセグメント境界と同じ程度観測網から離れ た場所にも震源が決定されていること, 岡野・木村 (1988)などの報告でもこの付近に浅い地震の震央がひ とつもプロットされていないことを考えると, 池田断首 と石槌断層のセグメント境界には地震はほとんど発生し ていないと考えるのが妥当であろう.

一方, MTL 直下で最も地震活動が活発なのは愛媛・ 徳島・香川県境周辺である.この付近には MTL の地表 トレースのギャップや屈曲の報告はないが, 愛媛・徳島 県境は峠（境目峠）になっており，MTLに沿ってはこの 付近で最も標高の高い場所である. また，この付近の MTL 露頭の野外調查結果 [例えば永井 (1978), 岡田 (1968)]によると, 境目峠付近を境にしてその東西で MTL の運動形態や形状が異なる。すすなお，相対变位 の上下成分は境目峠の東側が北側隆起, 西側が石㮸断層 と同じく南側隆起である. また, 浅部での傾斜方向は境 目峠の西側の部分が南傾斜で, 境目峠の東側および石槌 断層の傾斜方向と逆になっている. 境目峠付近にセグメ ント境界が存在するのか否かを知るにはこの付近の過去 の大地震の活動を明らかにする必要がある。しかし, 境 目峠付近におけるMTL の運動形態や形状の特殊性や現 在の地震活動が周辺に比べて高いことを考えると, 将来 この地域に発生する大地震の前兆現象が発現する可能性 


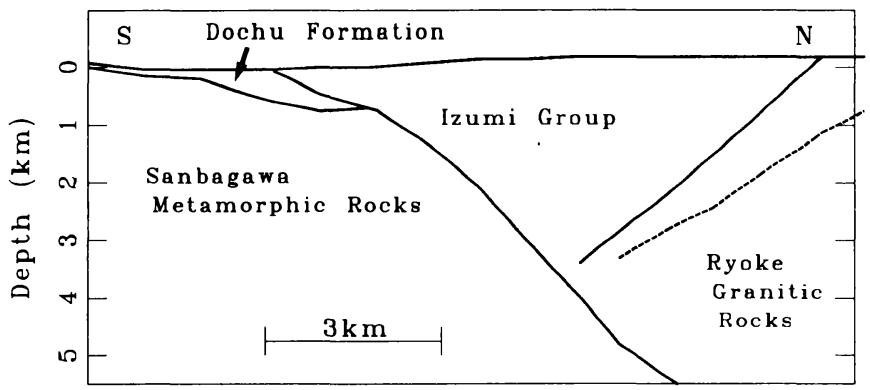

Fig. 6. Geological structure across the MTL in eastern Shikoku derived from a reflection seismic experiment conducted by ITo et al. (1993).

の高い場所として注目すべきであろう.

MTL の深部構造は現在までのところほとんど明らか にされていない，地震の震源分布はこの問題に関する重 要な情報を与えると考えられる. 今回得られた震源分布 のうち，MTL から南に向かって緩く傾斜する面状の分 布は, 岡野・木村 (1988) によれば,ささらに南方に続き御 荷鉾構造線の南にまで達する．従ってこれが MTL に相 当するあのと考えることは困難である.

前章であふれたように，木村・岡野 (1992) は深さ 8 $\mathrm{km}$ よりも浅い地震の震源分布に MTL 直下における鉛 直に近い角度で北傾斜する北落ちの食い違いを認めてい る. 木村・岡野 (1992) は，同様のずれが爱媛県西条市付 近を通る鉊直断面図などにあ認められることから，この 食い違いが MTL に相当するものだとしている，さら に, これらの食い違いの下方延長がマントル地震の震源 分布の傾斜角が变化する場所とほぼ一致ことから, MTL がモホ面付近まで連続していることを示唆してい る. しかし今回の観測結果から彼らが主張するような震 源分布のずれは認められなかった．この違いは，木村・ 岡野 (1992) が彼らが主張する震源分布の食い違いが MTL が鉛直に近いことの証拠のひとつとしていること から， MTL の深部構造を考える上で重要である．木 村・岡野 (1992) による震源分布の鉛直断面図には深さ 方向に長く $(5 \sim 10 \mathrm{~km})$ のびた震源の集中域がいくつか 見られ，これらが震源分布に鈴直に近い食い違いが認め られることの大きな要因となっていると思われる. 今回 の観測で得られた震源分布にも震源の集中域がいくつか 認められる (Fig. 5) が，その鉛直方向の広がりは高々 2 $\mathrm{km}$ 程度である. このことは, 木村・岡野 (1992) の震源 分布にみられる深さ方向に長く延びた震源の集中が, 震 源の深さの決定精度が十分でないための見かけのもので あることを示唆する. 今回の観測期間が約 9 か月と短か く震源決定された地震の数が 82 個之少なかったために 食い違いが羿められるに至らなかった可能性む残されて いるが，上のような理由で，震源分布にもとづいて
MTL が鉛直に近いとするのは根拠にそしいことと考え られる.

吉川・他 (1992) は和歌山県西部における油圧インパ ク夕を震動源とする反射法地震探查を行い, 約 $20^{\circ}$ で北 にゆるやかに傾斜するMTL からの反射波と考えられる 顕著な相か深度 $600 \mathrm{~m}$ 程度まで追跡されることを示し た。伊藤・他 (1993) は四国東部でバイブロサイスを用 いた反射法地震探査を行い深度約 $5 \mathrm{~km}$ までの構造を得 ている (Fig. 6). 深度 $1 \mathrm{~km}$ 以浅の構造は吉川・他 (1992)によるものと非常に類似している. それ以樑では MTL は傾斜角を約 $40^{\circ}$ に增して, 深度約 $3 \mathrm{~km}$ までは 三波川变性岩類と和泉層群の境界として, 深度約 $3 \mathrm{~km}$ 以深では三波川変性岩類と領家花凧岩類の境界として深 度約 $5 \mathrm{~km}$ まで追跡される. 今回得られた震源分布のう ち，MTL から北に向かって傾斜する分布は，面状の分 布か否かを判定するにはさらにデータを蓄積する必要が あるが，その北限の位置および傾斜角が伊藤・他 (1993) によって求められた地質境界としての MTL と比較的よ く一致する。このことは，これらの地震が三波川変性岩 類中の領家花岡岩類との境界に近い部分で発生している ことを示唆する.

\section{§6. おわりに}

徳島・香川・愛媛県境付近の地域の MTL 近傍に認め られる微小地震活動の震源分布と MTL の関連を明らか にする目的で, 6 観測点からなる小スパンの微小地震観 測を行った. 得られた震源分布の全体的特徴は岡野・木 村（1988）などによって既に報告されているものと調和 的であった。しかし，岡野・木村 (1988)，木村・岡野 (1992) が MTL が鉛直に近いことの証拠とした MTL 直 下における震源分布の食い違いが認められないなど重要 な点で相違が見られた。.今回の観測では震源決定された 地震の数が 82 個と少なく, 地震活動之 MTL の関連を 明らかにするという当初の目的は必ずしも十分達成され たわけではない，今回の精度良く決定された震源デー夕 
を使って周辺地域の既設の定常観測点の観測点補正値を 決定することなどにより，この地域の震源決定精度の向 上に役立つことが期待される.

\section{甜辞}

観測期間中は現地の多くの方々に大変お世話になりま した. 特に, 守谷 保・中泉信一・西山昭良・大西俊 春・漆川尊文・山口正子の各氏には, 観測場所として自 宅の一部を提供して頂きました，福井勝義・長瀬真央氏 をはじめ住鉱コンサルタント四国支店の方々には観測網 の維持に協力して頂きました. 高知大学・木村昌三氏と 匿名の查読者のコネントは原稿の改善に役立ちました. 以上の方々に記して感謝の意を表します。本研究は工業 技術院特別研究「地震発生の場とメカニズムに関する研 究」の一部として行われた.

\section{文献}

Hirata, N. and M. Matsu'ura, 1987, Maximumlikelihood estimation of hypocenter with origin time eliminated using nonlinear inversion technique, Phys. Earth Planet. Interiors, 47, 50-61.

井上 公・浅野周三・吉井敏剋 - 松村一男 - 村上寛史 佐々木嘉三・多田 堯, 1984,1980 年坂出・一宇爆 破地震動観測による四国東北部の地壳構造, 地震 2 , 37, 163-183.

伊藤 潔・吉井敏攰・浅野周三・佐々木嘉三・伊神 煇, 1982, 家島・鳥形山爆破地震動観測による四国地 域の地殻構造, 地震 2, 35, 377-391.

伊藤谷生・伊勢崎修弘・平田 直・浅沼俊夫・宮内崇 裕・松本みよ゙り・石田啓祐・村田明広・木村学・竹 下 徹・山北 聡・山口 覚・長谷川修一・奥池司 朗・前田卓哉・山口和雄 - 井川 猛 - 足立幾久, 1993, 四国東部, 中央構造線地下構造の総合物理探査 （その 1) 反射法地震探査, 地球惑星科学関連学会 1993 年合同大会予稿集, 168.

活断層研究会, 1980, 日本の活断層一分布図と資料, 東 京大学出版会.

木村昌三・岡野健之助, 1992, 四国の中央構造線およで その周辺地域についての地震学的考察, 地質学論集, 40, 187-195.

Matsuda, T., 1980, Active fault and damaging earthquakes in Japan-macroseismic zoning and precaution fault zones, in "Earthquake Prediction-An International Review", ed. by D. W. Simpson and P. G. Richards, Maurice Ewing Series 4, AGU, Washington D.C., 279-289.

Matsu'ura, M., 1984, Bayesian estimation of hypocenter with origin time eliminated, J. Phys. Earth, 32, 469-483.

三浦勝美 - 佃 為成 -三浦礼子・井上義弘, 1990, 四国
西部の中央構造線付近の微小地震活動, 地震学会講演 予稿集, No. 1, 97.

永井浩三, 1978, 伊予三島市付近の中央構造線, MTL, No. 3, 11-15.

小川光明 - 岡村 真 - 島崎邦彦 - 中田 高 -千田 昇・ 中村俊夫 - 宮武 隆 - 前本英明 - 堤 浩之, 1992, 伊 予灘北東部における中央構造線海底活断層の完新世活 動, 地質学論集, 40,75-97.

岡田篤正, 1968, 阿波池田付近の中央構造線の新期断層 運動, 第四紀研究, 7, 15-26.

岡田篤正, 1992, 中央構造線活断層系の活動区の分割試 案, 地質学論集, 40, 15-30.

岡田篤正・松田時彦・堤 浩之・諸岡達也・溝田健志, 1991, 中央講造線の最新活動は慶長地震か? 一中央 構造線父尾断層の徳島県市場町上喜来トレンチ調査, 地震学会講演予稿集, No. 2, 264.

岡野健之助・木村昌三, 1988 , 震源分布から見た四国に おける中央構造線, 地震 2, 41, 603-607.

Sato, Y., I. OChI and Y. KotaKe, 1967, Accuracy of the determination of earthquake source parameters in and around Japan, Bull. Earthq. Res. Inst., 45, $1-5$.

当舎利行・杉原光彦・西 祐司, 1989, 微小地震処理シ ステムの開発 (I), 昭和 63 年度サンシャイン計画研究 開発成果報告書「深部地熱資源探査技術に関する研 究」, 25-35.

当舎利行・杉原光彦・西 祐司, 1990, 地熱地帯の還元 井周刃での微小地震活動-1989 年, 滝/上地域での 臨時微小地震観湘に関連して一, 平成元年度サンシャ イン計画研究開発成果報告書「深部地熱資源探査技術 に関する研究」, 130-143.

佃 栄吉, 1989, 中央構造線の地震テクトニクス, 地震 学会講演予稿集, No. 2, 45.

佃 栄吉, 1990, 地震断層の形態の断層破壊過程, 構造 地質, No. 35, 103-112.

Tsutsumi, H., A. Okada, T. Nakata, M. Ando and T. Tsukuda, 1991, Timing and displacement of Holocene faulting on the Median Tectonic Line in central Shikoku, southwest Japan, J. Struct. Geol., 13, 227-233.

堤 浩之・岡田篤正 - 中田 高 - 安藤雅孝, 1992, 中央 構造線岡村断層の地表付近の構造と完新世の活動一 1988 年春季西条地区トレンチ発掘調査一, 地質学論 集, 40, 113-127.

渡辺 晃, 1971 , 近地地震のマグニチュード, 地震 2 , 24, 189-200.

山崎晴雄 - 佃 栄吉 - 奥村晃史 - 衣笠善博 - 岡田篤正 • 中田 高・堤 浩之・長谷川修一, 1992, 受媛県西条 市における中央構造線岡村断層のトレンチ発掘調查, 地質学論集, 40, 129-142.

吉川宗治・岩崎好規 - 井川 猛 - 横田 裕, 1992, 反射 法地震探査による和歌山県西部の中央構造線の地質構 造, 地質学論集, 40, 177-186. 